\title{
Connexin 43 Enhances the Adhesivity and Mediates the Invasion of Malignant Glioma Cells
}

\author{
Jane H.-C. Lin, ${ }^{1}$ Takahiro Takano, ${ }^{2}$ Maria Luisa Cotrina, ${ }^{2}$ Gregory Arcuino, ${ }^{2}$ Jian Kang, ${ }^{2}$ Shujun Liu, ${ }^{2}$ \\ Qun Gao, ${ }^{2}$ Li Jiang, ${ }^{2}$ Fanshu Li, ${ }^{2}$ Hella Lichtenberg-Frate, ${ }^{3}$ Sandra Haubrich, ${ }^{3}$ Klaus Willecke, ${ }^{3}$ \\ Steven A. Goldman, ${ }^{4}$ and Maiken Nedergaard ${ }^{2}$
}

Departments of ${ }^{1}$ Pathology and ${ }^{2}$ Anatomy and Cell Biology, New York Medical College, Valhalla, New York 10595, 3/nstitut für Genetik, Abteilung Molekulargenetik, University of Bonn, 53117 Bonn, Germany, and ${ }^{4}$ Department of Neurology and Neuroscience, Cornell University Medical College, New York, New York 10021

A hallmark of astrocytic tumors is their infiltrative nature. Although their aggressive and typically widespread dispersal in the adult brain differs fundamentally from that of other brain tumors, little is known about their cellular basis. Astrocytic tumors express the gap junction protein connexin 43 (Cx43), and we show here that Cx43 expression induced the morphological transformation of glioma cells into an epithelial phenotype. In a short-term aggregation assay, Cx43 expression was associated with a several-fold increase in the competence of glioma cells to aggregate. Antibodies directed against the extracellular domain of Cx43 restored the connexin-deficient phenotype, as manifested by a dose-dependent reduction in aggregation. Apart from their role in gap junction formation, connexins may therefore be considered a distinct class of membrane proteins with adhesive properties. Moreover, implanted Cx43-expressing glioma cells established functional gap junction channels with host astrocytes and dispersed through a substantially greater volume of brain parenchyma than mock- and mutant Cx43-transfected sister cells. Cx43 expression therefore may modulate not only the adhesion of astrocytes to one another, but the spread of glial tumor cells throughout astrocytic syncytia. These observations widen our concept of the potential interactions between tumor cells and their surroundings and suggest that both connexin proteins and their derived gap junctions are critical determinants of the invasiveness of central gliomas.

Key words: cell motility; astrocyte; gap junction; bystander death; brain tumor; rat
Malignant glioma is distinguished by the aggressive and widespread migration of glioma cells into surrounding brain tissue (Schiffer, 1997). The infiltrative growth at an early stage limits the efficacy of surgical resection and targeted radiotherapy, because the tumor has typically spread over considerable distances by the time of diagnosis. Despite aggressive treatment, the median life expectancy remains under 2 years (Kallio et al., 1991). In contrast, secondary brain tumors originating from neoplastic cells of metastatic origin typically grow as solid, well defined, and circumscribed tumors (Benedetti et al., 2000). The cellular basis for the widespread dissemination of astrocytic tumor cells is poorly understood.

It has been noted previously that most malignant gliomas express the gap junction protein connexin 43 (Cx43) (Shinoura et al., 1996; Huang et al., 1999; W. Zhang et al., 1999). Gap junctions are intercellular channels that allow direct passage of low molecular weight molecules between coupled cells. Gap junctions are found at early stages of embryogenesis and remain ubiquitous through ontogony. Connexins are expressed in a developmental and tissue-specific manner and play pivotal roles in phenotypic

Received May 23, 2001; revised March 4, 2002; accepted March 15, 2002.

This work was supported by National Institute of Neurological Disorders and Stroke/National Institutes of Health (Grants R01NS30007 and R01NS38073 to M.N. and R01NS29813 and R01NS33106 to S.G.), the American Heart Association (Grant 99-50994T to J.L.), the Mathers Charitable Foundation and Hereditary Disease Foundation (S.G.), and the German Research Association. We thank Hua Song and Gaby Hallas for technical assistance.

Correspondence should be addressed to Jane H.-C. Lin, Department of Pathology, Basic Science Building, New York Medical College, Valhalla, NY 10595. E-mail: jane_lin@nymc.edu.

Copyright (C) 2002 Society for Neuroscience $\quad 0270-6474 / 02 / 224302-10 \$ 15.00 / 0$ differentiation, pattern formation, and morphogenesis (Kumar and Gilula, 1996; Lin et al., 1998). Recent lines of evidence have implicated gap junctions in cytoskeletal organization, and $\mathrm{Cx} 43$ expression facilitates the migration of mouse neural crest cells (Huang et al., 1998).

In this study, we studied the impact of Cx43 expression on the adhesive and invasive properties of malignant gliomas. We observed that $\mathrm{Cx} 43$ enabled glioma cells to establish gap junctions with host astrocytes and dramatically altered their pattern of invasion. Cx43-expressing glioma cells disseminated freely throughout the brain parenchyma, whereas $\mathrm{Cx} 43$-deficient glioma cells migrated principally along the adluminal surfaces of the capillaries and blood vessels. Further analysis revealed that $\mathrm{Cx} 43$, in addition to its function as a channel, acted as an adhesion site that enhanced cellular aggregation. The adhesive actions of connexin proteins did not require the formation of functional channels and thereby were distinct from their role in the assembly and maintenance of gap junctions. Formation of functional channels appeared to be necessary for glial tissue invasion, but not for adhesion per se, in that a mutant $\mathrm{Cx} 43\left(\mathrm{Cx} 40^{*} 43 \mathrm{C} 3\right)$ that forms adhesive plaques, but not functional channels, failed to increase invasiveness. These observations indicate that connexin proteins have intrinsic properties as adhesive moieties and that formation of $\mathrm{Cx} 43^{+}$gap junctions between glioma cells and host astrocytes facilitates the parenchymal invasion of glial tumors.

\section{MATERIALS AND METHODS}

Cultures and transfection. Cortical astrocytes from 1-d-old postnatal (P1) rats were prepared and maintained as described previously (Nedergaard, 1994; Cotrina et al., 1998). Cultures were grown 2-6 weeks in vitro before 
use. cDNAs for $\mathrm{Cx} 43$ and $\mathrm{Cx} 32$ were ligated into the expression vectors pcDNA1 and pBEHpac18, which contain genes coding for geneticin and puromycin resistance, respectively (Elfgang et al., 1995). Chimeric constructs were generated by exchanging $\mathrm{Cx} 40$ domains for the corresponding domains of $\mathrm{Cx} 43$ by site-directed mutagenesis (Haubrich et al., 1996). The $\mathrm{Cx} 43$ point mutation, C61S, was generated by site-directed mutagenesis replacing the cysteine residue in position 61 with a serine residue. These mutant constructs were ligated to pBEHpac18 (Lin et al., 1998). Transfection of C6 glioma cells was performed using Superfect (Qiagen, Valencia, CA) according to the manufacturer's instructions. Three independent clones, transfected to stably express either one of the $\mathrm{Cx} 43$, $\mathrm{Cx} 40, \mathrm{Cx} 32, \mathrm{Cx} 40 * 43 \mathrm{C} 3, \mathrm{Cx} 40 * 43 \mathrm{E} 2$, or C61SCx 43 constructs or its respective expression vector (without a connexin insert), were used for all assays. Expression of $\mathrm{Cx} 43, \mathrm{Cx} 40$, and $\mathrm{Cx} 32$ was assayed both by immunolabeling with polyclonal antibodies (courtesy of B. Nicholson, SUNY, Buffalo, NY, and D. Paul, Harvard University, Boston, MA) and by functional dye transfer (Goldberg et al., 1995). Of note, all of the Cxas well as the mock-transfected clones selected for this study exhibited a proliferation rate that did not differ significantly from C6 wild type. Typically, the clones doubled in cell number every 26-28 hr (data not shown).

Immunocytochemistry and functional coupling assay. Immunostaining with antibodies against the extracellular domains of Cx43, E1 and E2 (see below), was performed as described (Laird and Revel, 1990). Briefly, cells grown on glass coverslips for $2 \mathrm{~d}$ were fixed for $15 \mathrm{~min}$ in $4 \%$ paraformaldehyde. After several washes in PBS, cells were treated with $10 \mathrm{~mm}$ Tris, $\mathrm{pH} 12.0$, containing $8 \mathrm{M}$ urea for $1 \mathrm{hr}$ at $37^{\circ} \mathrm{C}$ to facilitate access of the antibodies to the connexin extracellular domains. The remaining nonspecific binding sites were quenched with a blocking solution containing 2\% BSA in PBS for 45 min. Cells were then washed and incubated in primary antibody diluted in blocking solution for $1 \mathrm{hr}$ at room temperature. Binding of anti-E1 and -E2 antibodies was detected by FITC-conjugated goat anti-rabbit antibodies. Immunostaining with the other antibodies was performed as described (Cotrina et al., 1998).

The dye transfer technique was adapted from Goldberg et al. (1995). Cells were loaded with 5 (and 6)-carboxy-2', $7^{\prime}$-dichlorofluorescein diacetate (CDCF diacetate) for $5 \mathrm{~min}$, washed, and trypsinized. After resuspension, cells were labeled with $10 \mu \mathrm{M} \mathrm{DiIC}_{18}$ (Molecular Probes, Eugene, OR) for $10 \mathrm{~min}$ and mixed with unlabeled cells at a 1:250 ratio. One hour after plating of $10^{6}$ cells on $12 \mathrm{~mm}$ polylysine-coated coverslips, dye transfer from the $\mathrm{CDCF} / \mathrm{DiIC}_{18}$-labeled (donor) cells to unlabeled (recipient) cells was evaluated using confocal scanning microscopy. Counting of both the labeled donor cells and their recipients was performed manually. Coupling index was defined as the fraction of donor cells that transferred dye to surrounding cells, multiplied by the mean number of recipient cells. A minimum of 200 donor cells were evaluated for each coupling mixture. At least three independent runs were performed for each of the three clones expressing each of the connexin constructs. The effect of anti-E1 and -E2 antibodies on gap junction coupling was tested by preincubating astrocytes with the respective Fab fragments $(60 \mu \mathrm{g} / \mathrm{ml}$ for $1 \mathrm{hr}$ ) before the dye transfer assay.

Short-term aggregation assay. Confluent cultures were incubated in $\mathrm{Ca}^{2+} / \mathrm{Mg}^{2+}$-free HBSS containing $1 \mathrm{~mm}$ EDTA for $15 \mathrm{~min}$. The culture was then dissociated mechanically with a fire-polished Pasteur pipette coated with serum to ensure maximum separation of cells, centrifuged at $500 \mathrm{rpm}$ for $5 \mathrm{~min}$, and resuspended in fresh DMEM/F12 serum-free medium. Resuspension and centrifugation were repeated twice to remove EDTA. Runs containing cell clumps of $>1 \%$ of the population were discarded. A total of $4 \times 10^{5}$ cells were plated in $400 \mu \mathrm{l}$ serum-free $\mathrm{DMEM} / \mathrm{F} 12$ in wells of 24 -well plates. The plates were placed on a rotary shaker $(89 \mathrm{rpm})$ at $37^{\circ} \mathrm{C}$ in a $\mathrm{CO}_{2}$ incubator for $20 \mathrm{~min}$ and fixed by addition of $40 \mu \mathrm{l}$ of $37 \%$ formalin. Cellular clusters consisting of $>10$ cells were considered an aggregate (Götz et al., 1996). The extent of aggregation was counted by a blinded evaluator. Fab fragments of E1 and E2 polyclonal antibodies were added 10 min before the aggregation assay.

Peptide synthesis and production of antibodies. Peptides corresponding to the amino acid residues 46-76 (see Fig. 2A, E1) and 186-206 (see Fig. $2 A, E 2)$ of $\mathrm{Cx} 43$ gap junctional protein and polyclonal antibodies were produced by Genosys Biotechnologies, Inc. An Fab purification kit was used to prepare Fab fragments of each antibody, according to the manufacturer's instructions (Pierce Chemical Co., Rockford, IL) Before use, the Fab fragments were dialyzed against serum-free PBS and then concentrated by centrifugation through Centricon-30 filters.

Lucifer yellow diffusion. Eighteen-day-old Wistar rats of both sexes were anesthetized with a mixture of ketamine $(2 \mathrm{mg} / \mathrm{kg})$ and xylazine
(0.4 mg $/ \mathrm{kg})$. Approximately 50,000 5-(and-6)-(((4-chloromethyl)benzoyl)amino)tetramethylrhodamine (CMTMR) (Molecular Probes; labeled according to manufacturer's instruction)-labeled C6-Cx43, C6-mock, or C6-Cx40*43C3 cells (volume 0.5-0.7 $\mu \mathrm{l}$ ) were injected at a depth of 3.5 $\mathrm{mm}$ into the right striatum. Injection coordinates with regard to bregma were $1 \mathrm{~mm}$ posterior and $2.0 \mathrm{~mm}$ lateral. Three days later, coronal slices of $300 \mu \mathrm{m}$ were cut on a Vibratome (TPI, St. Louis, MO) using a slice-cutting solution containing (in $\mathrm{mm}$ ): $2.5 \mathrm{KCl}, 230$ sucrose, 1.25 $\mathrm{NaH}_{2} \mathrm{PO}_{4}, 10 \mathrm{MgSO}_{4}, 0.5 \mathrm{CaCl}_{2}, 10$ glucose. Slices were incubated in a standard slice solution containing (in $\mathrm{mM}$ ): $126 \mathrm{NaCl}, 2.5 \mathrm{KCl}, 1.25$ $\mathrm{NaH}_{2} \mathrm{PO}_{4}, 2 \mathrm{MgCl}_{2}, 2 \mathrm{CaCl}_{2}, 10$ glucose, and $26 \mathrm{NaHCO}_{3}$, gassed with $5 \% \mathrm{CO}_{2} / 95 \% \mathrm{O}_{2}$ at room temperature $\left(21^{\circ}-23^{\circ} \mathrm{C}\right)$, and mounted in a tissue chamber (1.5 ml volume) at the microscope stage as described earlier (Kang et al., 1998).

The CMTMR-labeled glioma cells were identified by both differential interference contrast (DIC) and fluorescence microscopy using a $40 \times$ water immersion lens (Olympus BX50WI, Olympus, Tokyo, Japan). Whole-cell recordings were obtained by using an Axopatch 200B amplifier connected to a separate Pentium PC computer. Recording electrodes with resistances of 3-7 M $\Omega$ were pulled from KG-33 glass capillaries using a P-97 micropipette puller (Sutter Instrument Co.). The intracellular solution for filling whole-cell electrodes contained (in $\mathrm{mM}$ ): 117 KGluconate, $13 \mathrm{KCl}, 2 \mathrm{MgCl}_{2}, 10 \mathrm{HEPES}$, and Lucifer yellow (4\%) (pH adjusted to 7.2 with $\mathrm{KOH}$, osmolarity 280 ). Recordings in which the seal resistance was $<3 \mathrm{G} \Omega$ were rejected. Lucifer yellow was allowed to equilibrate for $15 \mathrm{~min}$. Without removing the patch pipette, the slice was perfused with $4 \%$ paraformaldehyde. Twenty minutes later, the pipettes were carefully withdrawn, and the extent of Lucifer yellow diff usion was visualized by confocal microscopy, using a Bio-Rad MRC1000 mounted on an Olympus IX70 inverted microscope, with a $60 \times$ oil lens [numerical aperture (NA) 1.4] and a $5 \mathrm{~W}$ krypton-argon laser. The slices were postfixed for another $10-12 \mathrm{hr}$ at $4^{\circ} \mathrm{C}$, and after several washes in PBS they were stained for GFAP (G3893, Sigma) as described (Kang et al., 1998). Lucifer yellow, CMTMR, and Cy5 (GFAP) were excited using the 488, 568, and $648 \mathrm{~nm}$ lines, respectively.

Implantation, FITC-dextran injections, immunohistochemistry, and image analysis. Rats (male Wistar, 180-200 gm) were anesthetized with a mixture of ketamine $(80 \mathrm{mg} / \mathrm{kg})$ and xylazine $(10 \mathrm{mg} / \mathrm{kg})$ and placed in a stereotactic frame. Glioma cells were prelabeled with CMTMR and injected $\left(10^{6}\right.$ cells in a volume of $\left.2-3 \mu \mathrm{l}\right)$ at a depth of $6 \mathrm{~mm}$ in the right striatum with a Hamilton syringe. Injection coordinates with regard to bregma were $0.5 \mathrm{~mm}$ posterior and $3.0 \mathrm{~mm}$ lateral. Three to four days later, the deeply anesthetized rats received an intravenous injection of FITCdextran $\left(2 \times 10^{6} \mathrm{Da}, 1 \mathrm{ml}\right.$ of $50 \mathrm{mg} / \mathrm{ml}$; Sigma $)$ to outline the microvasculature (Morris et al., 1999; Zhang et al., 2001). These rats were decapitated $1 \mathrm{~min}$ later, and the brains were immersed in $4 \%$ paraformaldehyde. After postfixation for $48 \mathrm{hr}$, the brains were sectioned into $100-\mu \mathrm{m}$-thick slices by a vibratome. The slices were imaged under serial optical sectioning using $2 \times$ zoom at $0.5 \mu \mathrm{m}$ step-size with a $20 \times$ oil lens (NA 0.80 ) and reconstructed in three-dimension (3-D) using MacVol software (freely distributed for noncommercial use at http://www.strout.net/macsoft/macvol/ index.html). The number of CMTMR-labeled cells was quantified as a function of distance from the site of injection by a blinded observer Invading CMTMR-labeled tumor cells were scored as adluminal (cells in direct contact with vessels) or parenchymal (cells not in contact with vessels). 3-D reconstruction was used to ensure that all tumor cells were visualized throughout the thickness of the slice.

\section{RESULTS}

\section{Connexin expression increases the adhesive competence of glioma cells}

To establish whether connexin proteins per se regulated cellular phenotype, we studied the effects of forced $\mathrm{Cx} 43$ expression on the morphology of C6 glioma, a gap junction-deficient line (Zhu et al., 1991; Lin et al., 1998). Wild-type C6 cells, which are poorly coupled, grew as loosely packed elongated cells, only with much less cellular contact (Fig. $1 A$ ) compared with the Cx-expressing C6 cells even after prolonged culturing. Such forced expression of Cx43 (C6-Cx43) or Cx32 (C6-Cx32) increased coupling by $>10$ fold; the coupling indices for $\mathrm{C} 6-\mathrm{Cx} 43$ and $\mathrm{C} 6-\mathrm{Cx} 32$ cells were $7.0 \pm 0.07$ and $18.0 \pm 0.1$, respectively, whereas that of matched mock transfectants was $<0.3$ (Table 1). The Cx-transfected cells 


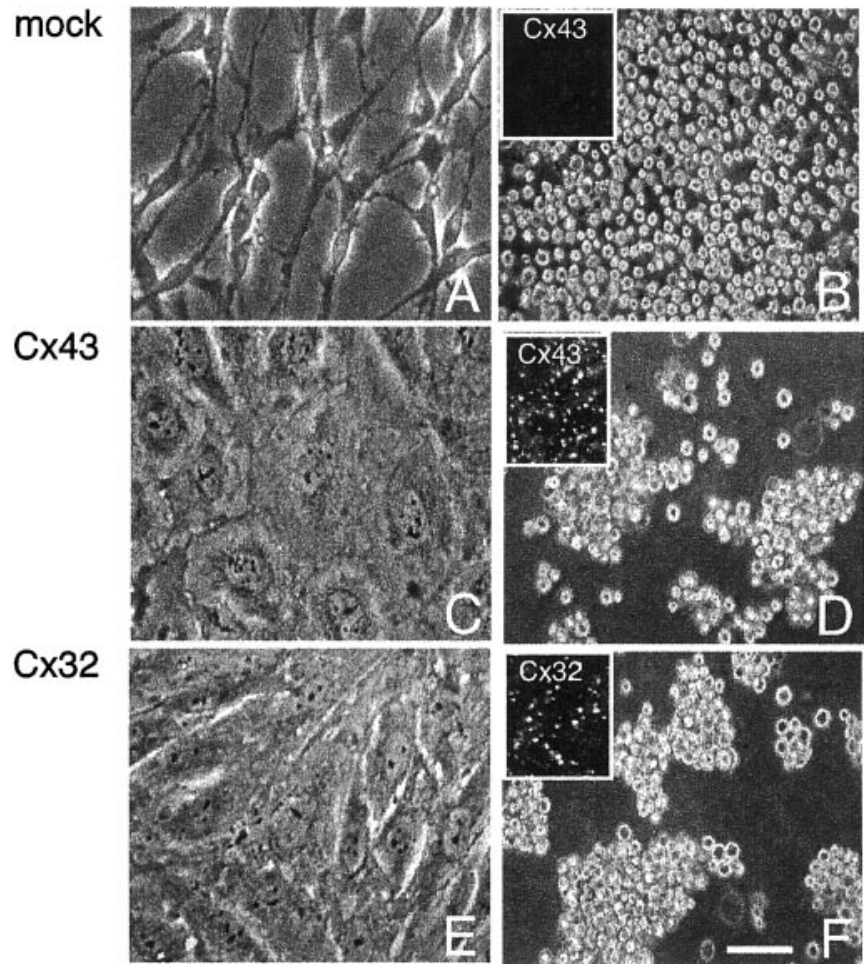

Figure 1. Forced expression of connexins is associated with epithelialization and adhesion. Forced expression of Cx-proteins yields both a phenotypic transformation and an increase in adhesiveness of C6 glioma cells. $A-C$, Phase micrographs of C6-mock transfected cells $(A), \mathrm{C6}-\mathrm{Cx} 43$ cells $(B)$, and C6-Cx32 cells $(C) . D-F$, Short-term aggregation of C6mock transfected cells $(D)$, C6-Cx43 cells $(E)$, and C6-Cx32 cells $(F)$. Forced expression of either $\mathrm{Cx} 43$ or $\mathrm{Cx} 32$ was associated with increased aggregation. Mock-transfected or wild-type C6 cells failed to aggregate. Insets, Immunolabeling of $\mathrm{Cx} 43$ or $\mathrm{Cx} 32$ in matched cultures. Scale bar: $A-C, 30 \mu \mathrm{m} ; D-F, 25 \mu \mathrm{m}$; insets, $60 \mu \mathrm{m}$.

flattened and established a monolayer of epithelial-like cells with contiguous contact (Figs. $1 B, 2 C$ ). This morphological transformation resembled that reported previously after induced expression of the cadherins and IgG-family cell adhesion molecules (Matsuzaki et al., 1990).

To test whether connexin expression was sufficient to permit intercellular adhesion, we next used a short-term aggregation assay (Takeichi, 1977; Nose et al., 1988). The basis for this assay is that the initial aggregation of dissociated cells reflects the functional expression of adhesive sites on the plasma membrane (Götz et al., 1996). We found that only 8-18\% of wild-type or mock-transfected $\mathrm{C} 6$ cells formed aggregates of much smaller sizes, whereas $54-90 \%$ of C6-Cx43 did so (Fig. $1 D-F$, Table 1). In addition, by comparison, the aggregates of the non-Cx expressers were much smaller. Exogenous expression of Cx40 (C6-Cx40) also increased aggregation (Table 1). Thus, connexin expression was associated with a general increase in the adhesivity of C6 cells.

\section{Antibodies directed against the extracellular loops of Cx43 decrease aggregation}

To analyze the potential adhesive function of $\mathrm{Cx} 43$, we raised antibodies against synthetic peptides composed of amino acids 46-76 and 186-206 of Cx43. These corresponded to the first and second external loops of the molecule, respectively, designated Cx43E1 and Cx43E2 (Fig. 2A). In confluent cultures of C6 cells, immunoreactive plaques were identified in regions of cell-cell contact by each of these antisera (Fig. $2 B, C$ ). Fab fragments of both antibodies inhibited formation of functional gap junction channels. The coupling indices, defined by the number of astrocytes labeled by single neighboring cells preloaded with the gap junction-permeable dye CDCF, decreased from $8.4 \pm 0.4$ in control cultures to $2.7 \pm 0.7$ in plates exposed to anti-Cx43E1 and $3.6 \pm 0.5$ in cultures exposed to anti-Cx43E2 [each at $30 \mu \mathrm{g} / \mathrm{ml}$; $p<0.0001$ by two-tailed, one-way ANOVA; $F=25.1$ (df $=4$, 19)]. Thus, gap junction-dependent dye transfer was reduced $69 \%$ by anti-Cx43E1 Fab ( $p<0.0001$ by post hoc Bonferroni $t$ test), and $57 \%$ by anti-Cx43E2 Fab $(p<0.0001)$ (Fig. $2 D, E)$.

We confirmed the specificity of $\mathrm{Cx} 43$-associated CDCF dye transfer by repeating the dye transfer assay after preabsorption of the antibodies with their cognate antigens and by the control addition of preimmune IgG Fab. As an additional control, we added Fab fragments directed against rat L1 protein (Goldman et al., 1996), a cell adhesion molecule of the $\operatorname{IgG}$ family that is expressed by C6 cells (Izumoto et al., 1996) but not involved in gap junction function (Dezawa and Nagano, 1996; Martini and Carenini, 1998). None of these treatments reduced dye coupling; the coupling indices of astrocytes exposed to naïve IgG Fab and anti-rat $\mathrm{L} 1 \mathrm{IgG}$ Fab were $8.8 \pm 0.5$ and $7.6 \pm 0.8$, respectively ( $p>0.5$ for each, relative to mock-transfected controls).

To test whether connexin proteins are themselves responsible for the connexin-associated increase in homotypic aggregation, we added Cx43-E1 and Cx43-E2 Fab fragments to freshly prepared suspension cultures of $\mathrm{C} 6-\mathrm{Cx} 43$ cells and assessed their aggregation. We observed a dose-dependent decrease in the number of cells in these aggregates, relative to controls that included PBS, preabsorbed Fab, normal rabbit sera and antiNgCAM ( $\alpha 8 \mathrm{D} 9$ ), and anti-L1 Fabs (Fig. 3A-D) (Goldman et al., 1996). Although the control Fabs were added in the highest protein concentration used $(60 \mu \mathrm{g} / \mathrm{ml})$, none exerted any demonstrable effect on the number of cells per aggregate (Fig. 3D). These results suggest that the increase in adhesivity of C6-Cx43 cells may result directly from homotypic interactions among connexin extracellular domains.

\section{Gap junction channel formation, but not permeability, is required for connexin-dependent adhesion}

The extracellular loops of most members of the Cx-family, with the exception of $\mathrm{Cx} 31$, contain three invariant cysteine residues, the conservation of which suggests their functional importance. Accordingly, site-directed mutagenesis of any of these cysteines results in loss of functional channel formation, despite maintained expression of the mutant connexin (Dahl et al., 1992; Foote et al., 1998). On this basis, we assessed the effect of exchanging the cysteine residue of position 61 of the $\mathrm{Cx} 43$ sequence on cell-cell adhesion. Three high-expression clones, stably transfected to express a cysteine-to-serine point mutation at residue 61 of Cx43 (C61S), were selected. Despite a high level of C61S-Cx43 expression, Cx43 immunoreactive plaques were not found at cellular interfaces. Instead, a diff use increase in cytosolic Cx43 immunoreactivity was evident (Fig. 4A). Dye coupling was $0.5 \pm 0.2$, not different from that of untransfected clones; similarly, aggregation was no better than that of untransfected controls $(4.0 \pm 0.5 \%$ of cells aggregated, relative to $5.0 \pm 1 \%$ of mock-transfected control cells; $n=8$ ) (Fig. $4 B$ ). Together, these data suggest that connexin-dependent adhesion likely requires the formation of gap junction plaques.

We next asked whether gap junction formation is required for connexin-dependent adhesion, or whether the docking of two 
Table 1. Percentage aggregation of $\mathrm{Cx}$ - and mock-transfected $\mathrm{C6}$ glioma cells

\begin{tabular}{|c|c|c|c|c|}
\hline & $\begin{array}{l}\text { Percentage of cells in } \\
\text { aggregates }\end{array}$ & $\begin{array}{l}\text { Percentage of donor cells } \\
\text { transferring dye }\end{array}$ & $\begin{array}{l}\text { Mean number of } \\
\text { receiving cells per } \\
\text { donor cell }\end{array}$ & $\begin{array}{l}\text { Coupling } \\
\text { index }\end{array}$ \\
\hline C6-Cx43 & $72 \pm 4$ & $49 \pm 4$ & $14 \pm 2$ & $7 \pm 0.07$ \\
\hline C6-Cx40 & $65 \pm 3$ & $55 \pm 2$ & $9 \pm 1$ & $5 \pm 0.2$ \\
\hline C6-Cx32 & $54 \pm 3^{*}$ & $89 \pm 3$ & $21 \pm 3$ & $18 \pm 0.1$ \\
\hline C6-mock 1 & $15 \pm 4^{*}$ & $13 \pm 1.2$ & $1.1=0.3$ & $0.14 \pm 0.04^{*}$ \\
\hline C6-mock 2 & $13 \pm 3^{*}$ & $0.8 \pm 0.2$ & $1.1 \pm 0.2$ & $0.01 \pm 0.005^{*}$ \\
\hline C6-mock 3 & $10 \pm 4^{*}$ & $18 \pm 1.2$ & $1.2 \pm 0.2$ & $0.2 \pm 0.1^{*}$ \\
\hline C6-WT & $18 \pm 3^{*}$ & $27 \pm 2$ & $3 \pm 0.1$ & $0.8 \pm 0.2^{*}$ \\
\hline
\end{tabular}

Quantitative analysis of short-term aggregation assays. This table lists the percentage of Cx- and mock-transfected C6 cells that form aggregates in suspension assay. Dye transfer assays of Goldberg et al. (1995) were used as described in Materials and Methods. All assays were performed in a minimum of three independent runs (range, 3-16; mean, 9). *, Significantly different from C6-Cx43 cells $(p<0.05)$. ANOVA for group comparison with post hoc $t$ test is used to establish significant difference between the groups. All numbers indicate \pm SEM.
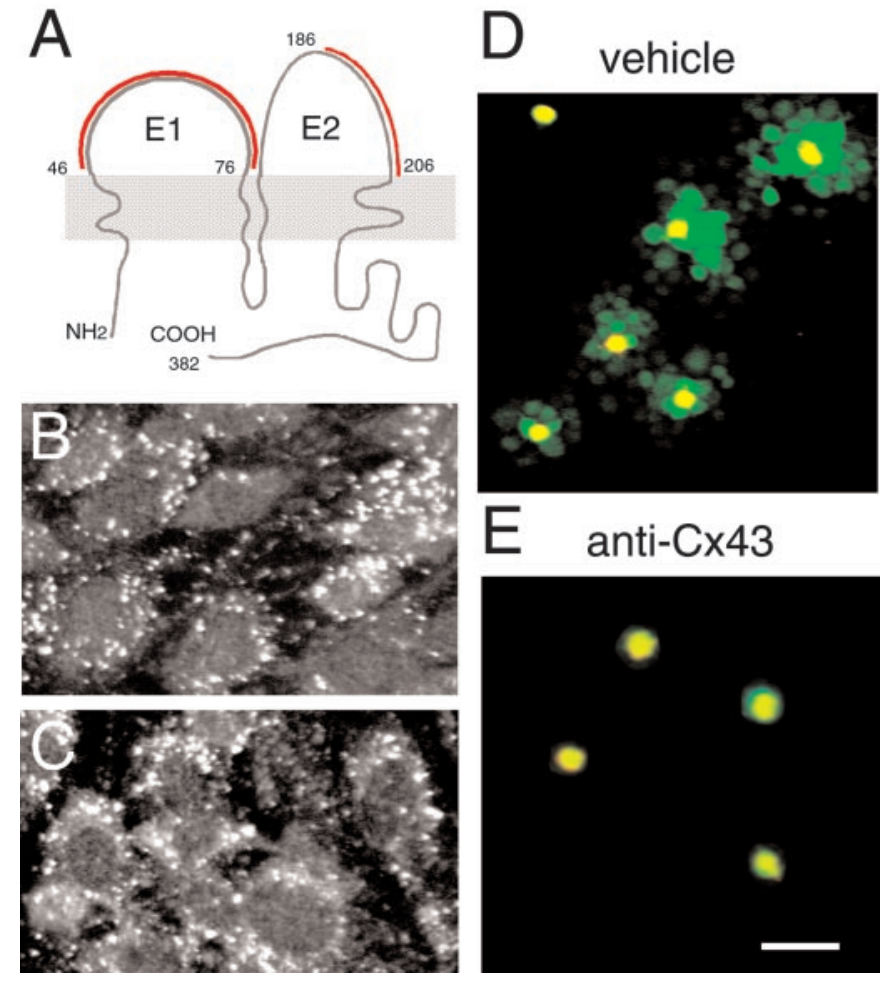

Figure 2. Antibodies directed against $\mathrm{Cx} 43$ diminish astrocytic dye coupling. All connexins share a similar topology consisting of four membrane-spanning segments with the $\mathrm{N}$ and $\mathrm{C}$ termini both on the cytoplasmic side, flanking two extracellular loops (E1 and E2). E1 and E2 are highly conserved regions, each containing three cysteine residues that dock hemichannels in neighboring cells to form a functional gap junction. $A$, Predicted topology of $\mathrm{Cx} 43$, with four transmembrane segments, two external loops (E1 and E2), and the $\mathrm{N}$ and $\mathrm{C}$ termini located at the cytoplasmic side of the membrane. Polyclonal antibodies were raised against segments that included amino acids 46-76 and 186-206 of E1 and $\mathrm{E} 2$, respectively (indicated by red lines). $B, C$, Immunolabeling of confluent cultures of cortical astrocytes with antibodies directed against E1 $(B)$ and $\mathrm{E} 2(C)$. Cx43 plaques were located in areas of cell-to-cell contact. $D$, $E$, Inhibition of dye transfer in cortical astrocytes after incubation in anti-E1 IgG Fab $(60 \mu \mathrm{g} / \mathrm{ml})(E)$, compared with vehicle-treated control cultures $(D)$. Gap junctional coupling was quantified by transfer of CDCF ( green) from DiIC ${ }_{18}$ labeled cells (red) to unlabeled identical cells. Donor cells appear yellow because of to the merge of red and green labeling. The coupling index of $8.4 \pm 0.4$ in control astrocytic cultures was reduced to $2.7 \pm 0.7$ in plates exposed to anti-Cx43E1 and $3.6 \pm 0.5$ in cultures exposed to anti-Cx43E2 $(p<0.0001$ by two-tailed, one-way ANOVA). Scale bar (shown in $E$ ): $B, C, 30 \mu \mathrm{m} ; D, E, 45 \mu \mathrm{m}$.
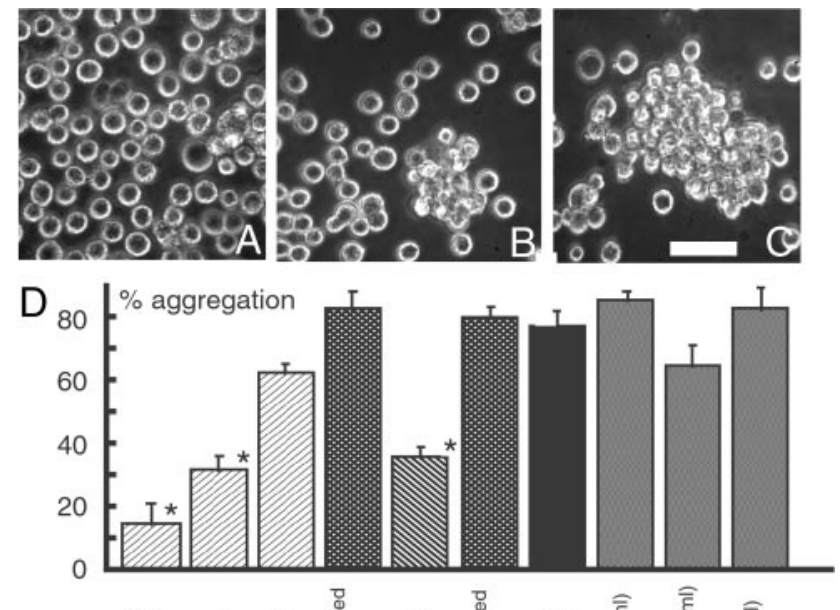

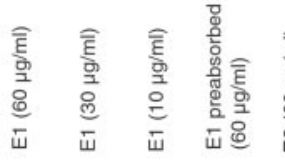

antiCx43 Fabs
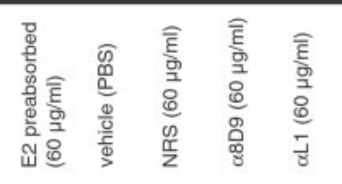

control Fabs
Figure 3. Dose-dependent inhibition of aggregation by anti-Cx43. A, Anti-Cx43 $(60 \mu \mathrm{g} / \mathrm{ml})$ almost completely blocked aggregation of C6-Cx43 cells, whereas $10 \mu \mathrm{g} / \mathrm{ml}$ anti-Cx43 $(B)$ attenuated but did not entirely block aggregation. In contrast, $>90 \%$ of vehicle-treated control cells formed aggregates $(C)$. Scale bar, $20 \mu \mathrm{m}$. $D$, Histogram summarizes the net proportion of aggregated cells in anti-Cx43-treated cultures $(10,30$, and $60 \mu \mathrm{g} / \mathrm{ml} \mathrm{Fab}$, and $60 \mu \mathrm{g} / \mathrm{ml} \mathrm{Fab}$ preabsorbed with respective blocking peptide). Controls included Fabs prepared from normal rabbit serum $(N R S)$, anti-NgCAM $(\alpha 8 D 9)$, and anti-rat L1 $(\alpha L 1)$ (Goldman et al., 1996), each at $60 \mu \mathrm{g} / \mathrm{ml}\left({ }^{*} p<0.01\right.$; ANOVA and post hoc Bonferroni $t$ test).

hemichannels is sufficient, in the absence of channel activity. To this end, chimeric constructs were used that had been produced by swapping corresponding domains of $\mathrm{Cx} 40$ with those of $\mathrm{Cx} 43$; the resultant $\mathrm{Cx} 40^{*} \mathrm{Cx} 43$ chimeras (Haubrich et al., 1996) were then expressed in C6 cells. Two of the constructs, Cx40*43E2 and $\mathrm{Cx} 40 * 43 \mathrm{C} 3$, formed abundant $\mathrm{Cx} 43$-immunoreactive plaques, which were nonetheless nonfunctional in that C6 transfectants that expressed these hybrid connexins exhibited neither dye transfer nor electrical coupling (Fig. 4C,E) (Haubrich et al., 1996). Importantly, the adhesivity of C6 cells increased substantially with the forced expression of each of these plaque-forming, but communication incompetent, connexin chimeras: Cx40*43E2and $\mathrm{Cx} 40 * 43 \mathrm{C} 3$-expressing C6 cells exhibited aggregation indices 


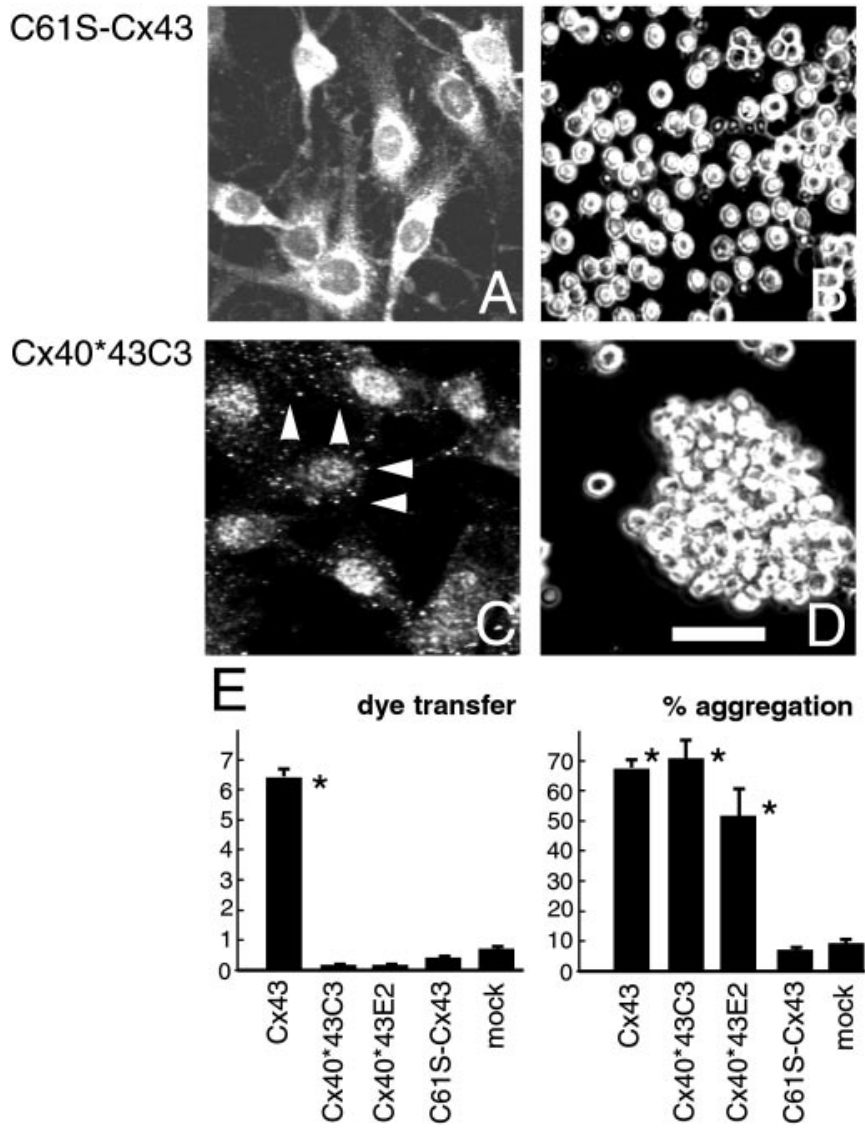

Figure 4. Separation and distinction of connexin-mediated adhesion and channel formation. Plaque formation, but not functional gap junction channels, was required for $\mathrm{Cx}$-mediated adhesion. $A$, Diff use $\mathrm{Cx} 43$ immunoreactivity in the cytosol of C6 cells transfected with mutant C61SCx43, which harbors a cysteine-to-serine point mutation at position 61 . The C61S-Cx43 protein did not form gap junction plaques and correspondingly did not increase the adhesive capability of sister cells $(B) . C$, C6 cells transfected with a chimeric construct $\mathrm{Cx} 40 * 43 \mathrm{C} 3$ displayed immunoreactive plaques at cell-cell interfaces (arrows) and an increase in cell aggregation $(D)$. Scale bar: $A, C, 25 \mu \mathrm{m} ; B, D, 30 \mu \mathrm{m}$. $E$, Histograms summarizing both the incidence of dye transfer and the percentage of aggregating cells among the clones studied ( ${ }^{*} p<0.01$; ANOVA and post hoc Bonferroni $t$ test).

of $52.7 \pm 12.7$ and $71.3 \pm 8.0 \%$, respectively, compared with $5.0 \pm$ $1.2 \%$ of mock-transfected controls and $4.0 \pm 0.5 \%$ of cells transfected with the dysfunctional mutant C61S-Cx43 $[p<0.0001$ by one-way ANOVA $(F=45.8$; df $=3,15)]$ (Fig. 4D,E). These results suggest that plaque formation is sufficient for connexindependent adhesion and that gap junctional permeability is not required.

\section{Implanted C6-Cx43 glioma cells form functional gap junctions with host astrocytes}

Given a role of $\mathrm{Cx} 43$ in the adhesive properties of glioma cells, we next tested the postulate that connexins directly mediated cellular interactions between glioma cells and astrocytes. Like most gliomas, primary astrocytes express high endogenous levels of Cx43. Because primary cells including astrocytes do not survive the shaking that is required for the short-term aggregation assay (Takeichi et al., 1981) (our observations), we implanted glioma cells labeled with the cell tracker CMTMR in striatum to test the proposition that tumor cells form functional gap junctions with host astrocytes. Our previous observation suggested that gap junctions are readily established between the two cell types in vitro (W. Zhang et al., 1999). Three days after implantation, freshly prepared vibratome sections were transferred to a recording chamber perfused with slice solution and viewed by DIC optics. Isolated CMTMR-labeled glioma cells that had migrated a minimum distance of $80 \mu \mathrm{m}$ from the tumor were patch clamped in the whole-cell current-clamp configuration. The pipette solution contained 4\% Lucifer yellow (MW 446). Of 12 C6-Cx43 cells studied, all transferred the dye to an average of $16 \pm 7$ surrounding cells (Fig. 5). In contrast to the widespread transfer of dye observed between implanted C6-Cx43 cells and their surroundings, five of five C6-mock showed minimal dye transfer $(0.3 \pm 0.3$ surrounding cells were Lucifer yellow positive). Similarly, hybrid $\mathrm{Cx} 40 * 43 \mathrm{C} 3$ cells that aggregated in vitro but formed nonfunctional gap junctional plaques (Fig. 4D,E) failed to establish any Lucifer yellow coupling with surrounding host cells when implanted in the brain (Fig. 5D).

In selected experiments, the cellular identity of the receiving cells was analyzed by staining against GFAP. As shown in Figure 5C, a CMTMR-labeled C6-Cx43 cell injected with Lucifer yellow was surrounded by several Lucifer yellow ${ }^{+}$cells that expressed astrocytic GFAP. Thus, Lucifer yellow diffused from implanted C6-Cx43 cells to surrounding GFAP-positive astrocytes, indicating that $\mathrm{Cx} 43$-expressing glioma cells establish functional gap junctions with host astrocytes. As will be clear in the next section, the ability to communicate with host cells is important for the glioma implants to infiltrate and establish themselves in the brain.

\section{C6-Cx43 cells aggressively infiltrate host brain}

We next asked whether gap junction communication regulates the mode of tumor cell invasion. CMTMR-labeled glioma cells were implanted, and $100 \mu \mathrm{m}$ vibratome sections were prepared after paraformaldehyde fixation $4 \mathrm{~d}$ later. To discriminate between migration along brain vessels versus parenchymal invasion, we initially labeled the vascular bed with antibodies directed against either a rat endothelial cell antigen (RECA) or against laminin enriched in the basal lamina of brain vessels. To ensure that the entire vasculature was visualized, intravenous administration of fluorescein-dextran $\left(2 \times 10^{6} \mathrm{Da}\right)$ was also used in some animals (Z. Zhang et al., 1999; Morris et al., 2000). Double staining revealed that fluorescein-dextran and labeling against either RECA or laminin outlined brain vessels without major differences. Serial optical sections were obtained through the entire thickness of the sections $(100 \mu \mathrm{m})$ by confocal microscopy and 3-D reconstructed using MacVol software.

Remarkably, the pattern of tissue invasion of $\mathrm{Cx} 43^{+} \mathrm{C} 6$ cells differed significantly from $\mathrm{Cx}$-deficient cells. To be sure, all implanted clones were noted to invade brain along the vasculature. Four days after implantation, both $\mathrm{Cx} 43^{+}$and $\mathrm{Cx} 43^{-}$tumor cells were regularly found associated with vessels several millimeters from the site of implantation (Fig. $6 A-D$ ). However, only $\mathrm{Cx} 43$ expressing cells exhibited a significant extent of parenchymal invasion with a large fraction of the tumor cells freely dispersed in normal brain tissue (Fig. 6B). In contrast, essentially all invading $\mathrm{Cx}$-deficient cells migrated along and were restricted to the vasculature. To quantify these observations, confocal images of 4-day-old implants were used to score migrating glioma cells, as a function of their distance from the injection site. This allowed us to differentiate between adluminal (in direct contact with vessels) and parenchymal (not in contact with vessels) migrants among the implanted cells. For example, just $2 \mathrm{~mm}$ from the tumor, the number of $\mathrm{C} 6-\mathrm{Cx} 43^{+}$cells in the parenchyma was $>30$-fold 
A

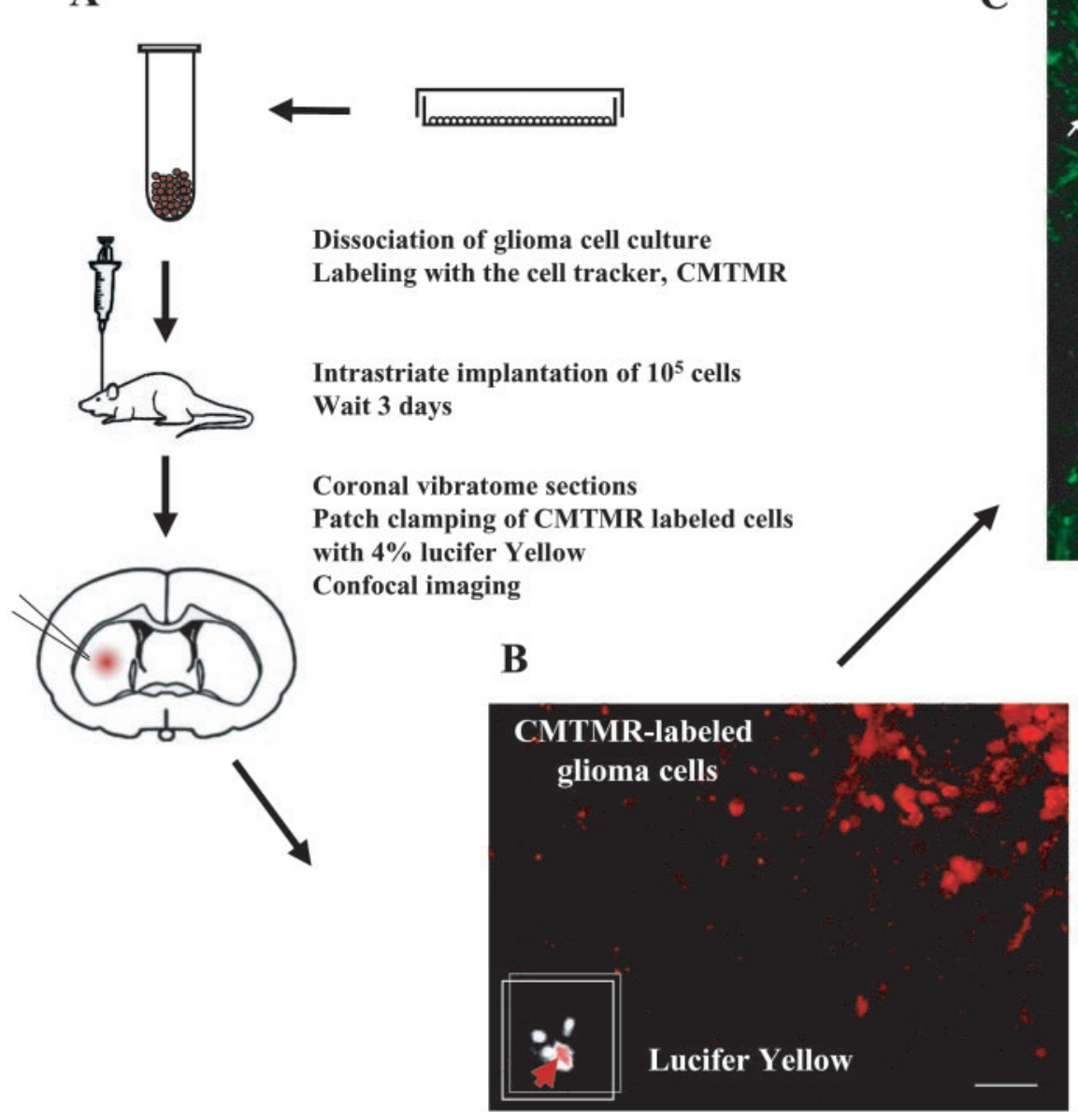

C

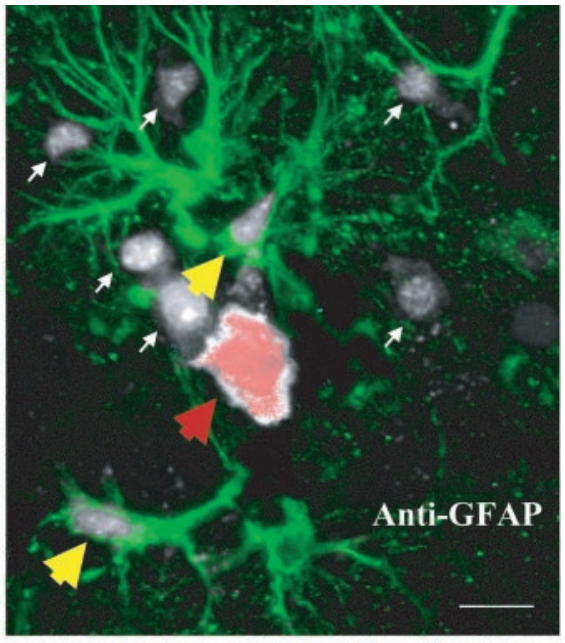

4\% paraformaldehyde AntiGFAP

Confocal imaging

Figure 5. Implanted glioma cells establish functional gap junctions with host astrocytes. Intercellular transfer of Lucifer yellow from CMTMR-labeled glioma cells (C6-Cx43) to GFAP-positive astrocytes. $A$, Diagram illustrating preparation and intrastriate implantation of glioma cells labeled with the cell tracker, CMTMR. Three days later, vibratome sections were prepared, and isolated CMTMR-labeled glioma cells that had migrated a minimum of $80 \mu \mathrm{m}$ from the injection site were patch clamped with a pipette solution containing $4 \%$ of the gap junction permeable dye Lucifer yellow. $B$, Confocal image of the live slice obtained during the experiment illustrating the CMTMR-labeled glioma cells (red) and Lucifer yellow (white). The impaled CMTMR-labeled glioma cell is marked by a red arrowhead. $C$, Confocal imaging of the same field after the slice was fixed and immunostained for GFAP (green). Lucifer yellow transferred from the CMTMR-labeled glioma cell (red arrowhead) to two GFAP-positive astrocytes (yellow arrowhead) and six GFAP-negative (small white arrow) neighboring cells. Scale bars: $B, 100 \mu \mathrm{m} ; C, 20 \mu \mathrm{m}$.

higher than any of the other clones studied. In contrast, all clones regardless of their $\mathrm{Cx}$ expression or coupling capacity with host cells migrated equally well (in terms of both distance and number of cells) along the vessels. Of note, although a significant fraction of invading C6-Cx43 cells were scored as adluminal because they contacted microvessels, their attachment was notably weaker than that of mock-transfected C43-deficient cells, which tightly ensheathed the microvessels (Fig. 6, compare $B, C$ ).

\section{Connexin-dependent adhesion was necessary but not sufficient for parenchymal invasion}

We next studied the invasive pattern of primary cultured astrocytes (first passage of astrocytic cultures prepared from P1 rats) after implantation. Astrocytes dispersed freely through the brain parenchyma in adult brain in a pattern very similar to $\mathrm{C} 6-\mathrm{Cx} 43^{+}$ cells (Fig. 6, compare $A, B$ ). Like C6-Cx43 cells, astrocytes only loosely contacted the microvasculature and were primarily embedded in the brain tissue. In contrast, C6-Cx32 cells did not demonstrate an increased potential for migration within the parenchyma, presumably because C6-Cx32 did not form gap junctions with $\mathrm{Cx} 43$-expressing astrocytes; their predominant pattern of invasion was adluminal and similar to $\mathrm{Cx}$-deficient clones (Fig. $6 E$ ). Together, these observations suggest a prominent role of $\mathrm{Cx} 43$ in parenchymal invasion of implanted glia. Because expression of the nonf unctional $\mathrm{Cx} 40 * 43 \mathrm{C} 3$ chimera did not enable the tumor cells to leave the vessels (Fig. 6D,E), our observations argue that the adhesive properties of $\mathrm{Cx}$-proteins alone are not sufficient to support aggressive tissue penetration by either primary glia or tumor cells. Rather, formation of functional $\mathrm{Cx} 43$ gap junction channels with host astrocytes may be a prerequisite for parenchymal invasion.

\section{DISCUSSION}

Our results show that $\mathrm{Cx} 43$ expression enables glioma cells to interact and establish functional gap junctions with astrocytes in the adult rat brain. In addition, $\mathrm{Cx} 43$ expression facilitated direct parenchymal invasion resulting in roughly 30 -fold more $\mathrm{Cx} 43$ expressing cells embedded in normal brain parenchyma, as early as $4 \mathrm{~d}$ after implantation, compared with $\mathrm{Cx}$-deficient clones. The invasion pattern of $\mathrm{C} 6-\mathrm{Cx} 43$ cells may result from their ability to form functional gap junction channels with host astrocytes. This 

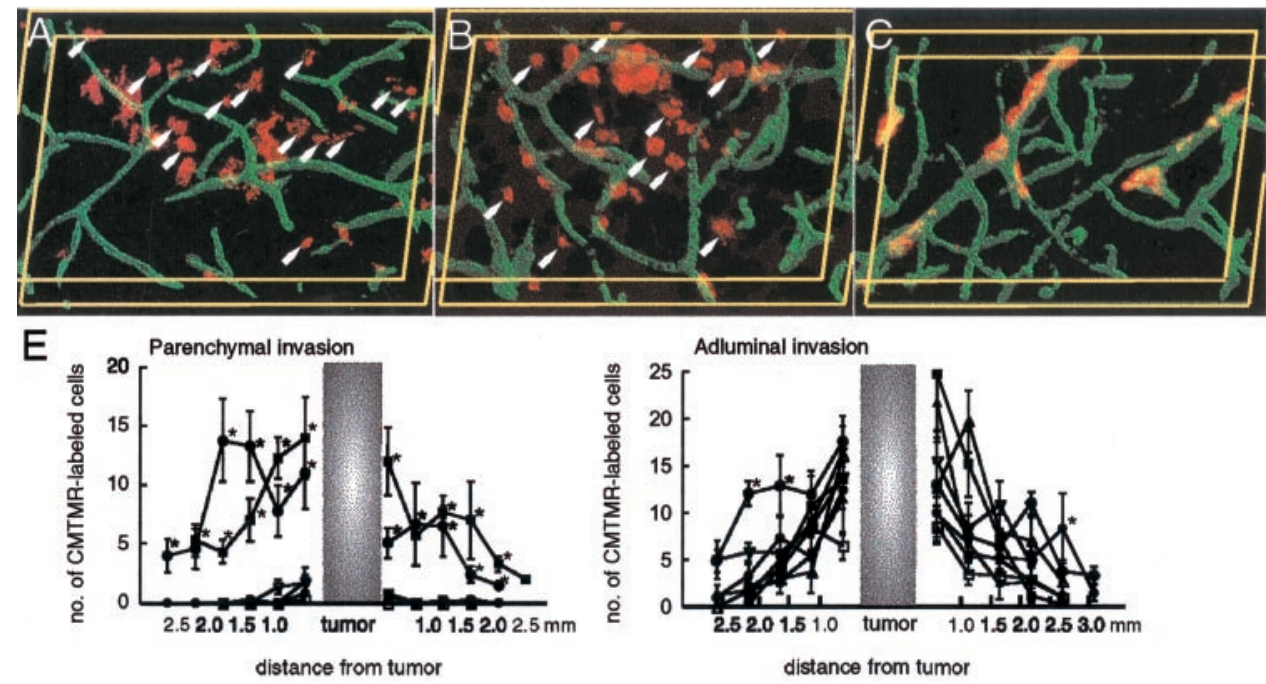

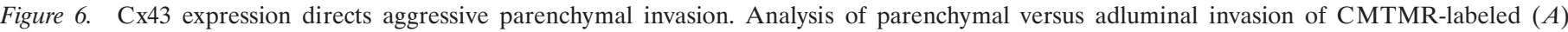

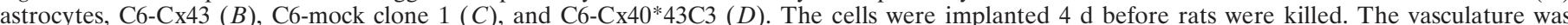

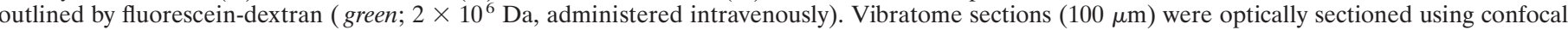

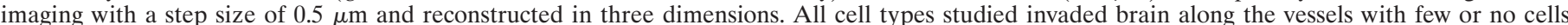

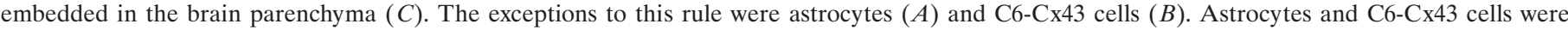

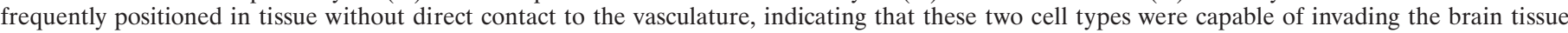

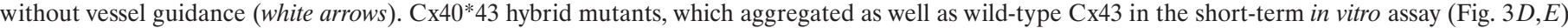

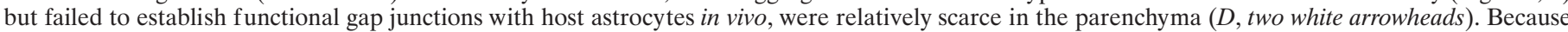

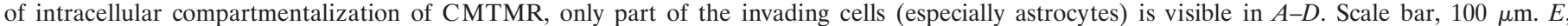

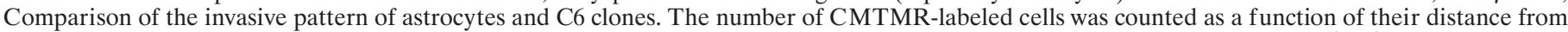

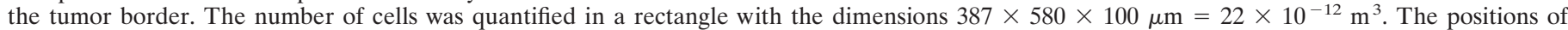

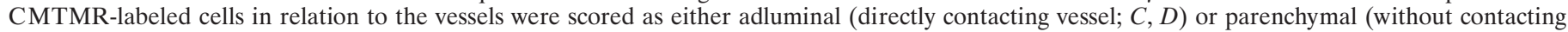

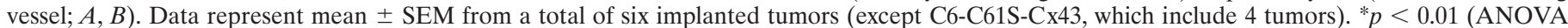
and post hoc Bonferroni $t$ test).

conclusion is supported by the notion that glioma cells expressing the nonfunctional $\mathrm{Cx} 40 * \mathrm{Cx} 43$ chimeras or the $\mathrm{Cx} 43$ point mutation (C61S-Cx43) did not display an increased propensity for parenchymal dissemination. Thus, it is likely that exchange of signals or metabolites relayed via gap junction channels with host astrocytes is a critical determinant in parenchymal invasion. For example, glucose and ATP are rapidly exchanged across homotypic Cx43 gap junction channels (Goldberg et al., 1998). An unrestricted supply of energy metabolites from surrounding astrocytes may enable the metabolically highly active glioma cells to disperse more rapidly. Similar conclusions on the effect of gap junction coupling were drawn by a study of the migration rate of cardiac neural crest cells, which was increased in transgenic mouse embryos overexpressing $\mathrm{Cx} 43$ but reduced in $\mathrm{Cx} 43$ knockout embryos (Huang et al., 1998). In contrast, glioma cells transfected with $\mathrm{Cx} 32$, a gap junction protein not expressed by astrocytes, invaded brain in a pattern very similar to the $\mathrm{Cx}$-deficient clones. The C6-Cx32 cells were highly coupled among themselves but were unable to establish gap junction channels with astrocytes because of the inability of $\mathrm{Cx} 32$ and $\mathrm{Cx} 43$ hemichannels to form functional channels (Elfgang et al., 1995). Together, these observations suggest that parenchymal invasion is dictated by the formation of functional coupling between glioma cells and parenchymal astrocytes.

\section{Connexins as adhesion molecules}

Another conclusion from this study is that connexins, with $\mathrm{Cx} 43$ as our prototype, have intrinsic competence as adhesion molecules. These results are consistent with the previous report that antibodies directed to extracellular domains of $\mathrm{Cx} 43$ not only inhibited functional coupling, but also increased the ultrastruc- turally defined distance between adjacent cells (Meyer et al., 1992). Similarly, disruption of traditional adhesion molecules has been described as having a marked influence on gap junction formation. Treatment with antibodies against cadherins or $\mathrm{N}$-CAM inhibited gap junction-mediated dye transfer, whereas transfection of poorly coupled cell lines with cDNA E-cadherin increased gap junction coupling (Matsuzaki et al., 1990; Jongen et al., 1991). Thus, connexin-dependent adhesion is likely modulated by other adhesion molecules.

It has long been recognized that hydrophobic interactions of apposing connexins provide for exceptionally strong binding. Chaotropic agents such as urea are required to split established gap junction channels into two separate membranes (Manjunath et al., 1984; Ghoshroy et al., 1995). Indeed, the intercalated discs are ripped from the plasma membrane of one cell to be retained by its neighbor rather than being split into their component membranes when myocytes are dissociated (Severs et al., 1990). Several electron microscopic studies identified double membrane, intracellular structures termed annular junctions or gap junction profiles (Larsen et al., 1979; Mazet et al., 1985). Recently, using green fluorescent protein-tagged and antibody-tagged Cx43 in cocultures, Jordan et al. (2001) demonstrated internalized gap junctions as the origin of annular junctions. Thus, migrating cells may internalize gap junction plaques as they move along and establish new contacts.

\section{Gap junctions in cell migration}

Several previous reports support a role for gap junctions in cell migration. After ischemia-reperfusion, leukocytes form gap junctions with endothelial cells (Jara et al., 1995). At brain stab wounds, microglia progressively accumulate and form aggregates 
that show $\mathrm{Cx} 43$ immunoreactivity at interfaces between cells (Eugenin et al., 2001). el-Sabban and Pauli (1994) reported a critical interdependence between the adhesion of lung-metastatic cancer cells to endothelial cells and their communication. In human melanoma lesions, the level of Cx26 is significantly upregulated in melanoma cells invading the dermis, and there is a strong correlation between the competence of the cells for coupling with endothelial cells and metastasis (Ito et al., 2000). Indeed, the fact that the scaffolding protein, zonula occludens, which associates with tight junction, cytoskeleton, and signal transduction molecules, colocalizes with $\mathrm{Cx} 43$ at gap junctions in several cell types suggests that $\mathrm{Cx} 43$ may have a wide range functions in cell-cell signaling (Giepmans and Moolenaar, 1998; Toyofuku et al., 1998, 2001; Laing et al., 2001).

\section{Connexin-dependent migration recapitulates aspects of developmental gliogenesis}

The ability of connexin hemichannels to serve as adhesion molecules in vitro suggests a new role for them in normal development. In particular, connexins appear sufficiently early in development that they might fulfill a role in the histiotypic organization of the early nervous system (Keane et al., 1988) as well as in the parenchymal transit of its connexin-expressing cells. Connexin family members also play an important role in gap junctiondependent intercellular calcium signaling (Cornell-Bell et al., 1990; Nedergaard, 1994). Two likely sites for connexin to exercise its dual roles in adhesion and signaling are in the embryonic neuroepithelium and adult astrocytic network. In the developing telencephalic ventricular zone, Cx43-dependent adhesion may contribute to the establishment of gap junction-coupled microdomains (Minkoff et al., 1991), which are predictive of later functional associations among the neurons generated therein (Peinado et al., 1993; Yuste et al., 1995). In the adult, the most prominent role of $\mathrm{Cx} 43$ may be in mediating interglial interactions. In contrast to the extensive literature describing interneuronal and interneuritic adhesive mechanisms within the CNS, little is known of the molecules mediating interastrocytic adhesion. Despite a likely role for cadherin family members in this process, they have not been shown to play a prominent role in interglial adhesion (Schnadelbach et al., 2000). Thus, our observation that connexins greatly enhance aggregation suggests that they may participate in stabilizing the astrocytic network of the adult brain.

\section{Pericapillary migration by connexin nulls reflects another conserved developmental strategy}

The relatively connexin-independent migration of both normal astrocytes and glioma cells along the adluminal surface of the capillary microvasculature suggests that the vascular basal laminas and adluminal cell surfaces may provide especially permissive environments for glial invasion, whether by normal cells or gliomatous transformants. This observation recalls both the preferential migration of ventricular zone daughter cells and newly generated neurons on brain microvascular endothelial cells (Leventhal et al., 1999) and the co-association of mitotic progenitors in the brain with capillary endothelial cells (Palmer et al., 2000). The latter is attributable at least in part to the release of humoral neurotrophins, including BDNF, by the local capillary endothelium. As a result, the capillary microvasculature may act as a source of neurotrophic cytokines that both attract and direct neuroblastic invasion of the brain parenchyma from the germinative ventricular zone neuroepithelium (Leventhal et al., 1999).
This theme, of immature cell migration along microvascular walls that support the adherent migrants through the release of neurotrophic cytokines, may be a conserved strategy in both embryonic and adult brain development. In the case of gliomatous invasion, these mechanisms in effect may be both capitalized on and subverted by infiltrating tumor cells, which may indeed share many features of both ontogeny and signal response with immature neural progenitor cells.

Traditionally, loss of gap junction coupling has been implicated in malignant transformation; several lines of evidence indicate that Cx43 expression decreases as the grade of gliomas/astrocytomas worsens (Shinoura et al., 1996; Huang et al., 1999; Soroceanu et al., 2001). Forced expression of $\mathrm{Cx} 43$ has been shown to inhibit proliferation of $\mathrm{C} 6$ cells both in vitro and in vivo, whereas expression of a nonfunctional $\mathrm{Cx} 43$ mutant reverted the cells to an anaplastic cell type possibly by acting as a dominant negative inhibitor of Cx43 (Zhu et al., 1992; Omori and Yamasaki, 1998). The loss of gap junction coupling with tumor progression may render the tumor less responsive to gap junctiondependent therapeutic strategies.

In this regard, an emerging strategy for cancer gene therapy involves the transfer of the herpes simplex virus thymidine kinase (HSVtk) gene into tumor cells, rendering them susceptible to the cytotoxic effects of ganciclovir. However, gap junctions between tumor cells facilitate the intercellular spread of thymidine kinaseactivated ganciclovir, thereby creating a bystander effect that may kill tk(-) cells, both neoplastic and normal (Mesnil et al., 1996; Shinoura et al., 1996). Although bystander death of tk(-) cells has been reported previously only in other neighboring tumor cells, our observations would predict that by virtue of the coupling between normal astrocytes and $\mathrm{Cx} 43^{+}$glioma cells (W. Zhang et al., 1999), normal astrocytes would similarly succumb to bystander death after gangiclovir administration after HSVtk delivery. Perhaps even more worrisome, the heterotypic coupling of astrocytes and oligodendrocytes (Nagy and Rash, 2000) might similarly encourage the transfer of tk-metabolized ganciclovir toxicity to local oligodendrocytes. These potential toxic sequelae of tk-dependent ganciclovir tumoricide may be particularly worrisome in light of recent proposals to use cotransfection strategies with HSVtk and $\mathrm{Cx} 43$ to sensitize a large fraction of tumor cells to ganciclovir (Marconi et al., 2000; Namba et al., 2000). We would predict, on the basis of the findings reported here, that this might both increase local toxicity among non-neoplastic cells and simultaneously encourage the Cx-dependent migration and invasion of the tumor cells themselves. This might well increase the invasive potential of the tumor, perhaps disproportionately to whatever oncolytic effects are achieved.

We conclude that $\mathrm{Cx} 43$-expressing glioma cells establish functional gap junctions with host astrocytes. This observation expands our understanding of the cellular interactions between tumor cells and their surroundings. Gap junctions are essential for cell signaling among electrically unexcitable cells, and signals relayed through gap junction channels may regulate and direct the mobility of invading glioma cells.

\section{REFERENCES}

Benedetti S, Pirola B, Pollo B, Magrassi L, Bruzzone MG, Rigamonti D, Galli R, Selleri S, Di Meco F, De Fraja C, Vescovi A, Cattaneo E, Finocchiaro G (2000) Gene therapy of experimental brain tumors using neural progenitor cells. Nat Med 6:447-450.

Cornell-Bell AH, Finkbeiner SM, Cooper MS, Smith SJ (1990) Glutamate induces calcium waves in cultured astrocytes: long range glial signaling. Science 247:470-474.

Cotrina ML, Kang J, Lin JH, Bueno E, Hansen TW, He L, Liu Y, 
Nedergaard M (1998) Astrocytic gap junctions remain open during ischemic conditions. J Neurosci 18:2520-2537.

Dahl G, Werner R, Levine E, Rabadan-Diehl C (1992) Mutational analysis of gap junction formation. Biophys J 62:172-180.

Dezawa M, Nagano T (1996) Immunohistochemical localization of cell adhesion molecules and cell-cell contact proteins during regeneration of the rat optic nerve induced by sciatic nerve autotransplantation. Anat Rec 246:114-126.

Elfgang C, Eckert R, Lichten-Frate H, Butterweck A, Traub O, Klein R, Hulser D, Willecke K (1995) Specific permeability and selective formation of gap junction channels in connexin transfected HeLa cells. J Cell Biol 129:805-817.

el-Sabban ME, Pauli BU 1994 Adhesion-mediated gap junctional communication between lung-metastatic cancer cells and endothelium. Invasion Metastasis. 14:164-176.

Eugenin EA, Eckardt D, Theis M, Willecke K, Bennett MV, Saez JC (2001) Microglia at brain stab wounds express connexin 43 and in vitro form functional gap junctions after treatment with interferon-gamma and tumor necrosis factor-alpha. Proc Natl Acad Sci USA 98:4190-4195.

Foote CI, Zhou L, Zhu X, Nicholson BJ (1998) The pattern of disulfide linkages in the extracellular loop regions of connexin 32 suggests a model for the docking interface of gap junctions. J Cell Biol 140: 1187-1197.

Ghoshroy S, Goodenough DA, Sosinsky GE (1995) Preparation, characterization, and structure of half gap junctional layers split with urea and EGTA. J Membr Biol 146:15-28.

Giepmans BN, Moolenaar WH (1998) The gap junction protein connexin43 interacts with the second PDZ domain of the zona occludens-1 protein. Curr Biol 8:931-934.

Goldberg GS, Lampe PD, Sheedy D, Stewart CC, Nicholson BJ, Naus CC (1998) Direct isolation and analysis of endogenous transjunctional ADP from Cx43 transfected C6 glioma cells. Exp Cell Res 239:82-92.

Goldberg S, Bechberger J, Naus C (1995) A pre-loading method of evaluating gap junctional communication by fluorescent dye transfer. BioTechnique 18:490-497.

Goldman SA, Williams S, Barami K, Lemmon V, Nedergaard M (1996) Transient coupling of Ng-CAM expression to NgCAM-dependent calcium signaling during migration of new neurons in the adult songbird brain. Mol Cell Neurosci 7:29-45.

Götz M, Wizenmann A, Reinhardt S, Lumsden A, Price J (1996) Selective adhesion of cells from different telencephalic regions. Neuron 16:551-564.

Haubrich S, Schwarz HJ, Bukauskas F, Lichtenberg-Frate H, Traub O, Weingart R, Willecke K (1996) Incompatibility of connexin 40 and 43 hemichannels in gap junctions between mammalian cells is determined by intracellular domains. Mol Biol Cell 7:1995-2006.

Huang GY, Cooper ES, Waldo K, Kirby ML, Gilula NB, Lo CW (1998) Gap junction-mediated cell-cell communication modulates mouse neural crest migration. J Cell Biol 143:1725-1734.

Huang RP, Hossain MZ, Sehgal A, Boynton AL (1999) Reduced connexin43 expression in high-grade human brain glioma cells. J Surg Oncol 70:21-24.

Ito A, Katoh F, Kataoka TR, Okada M, Tsubota N, Asada H, Yoshikawa K, Maeda S, Kitamura Y, Yamasaki H, Nojima H (2000) A role for heterologous gap junctions between melanoma and endothelial cells in metastasis. J Clin Invest 105:1189-1197.

Izumoto S, Ohnishi T, Arita N, Hiraga S, Taki T, Hayakawa T (1996) Gene expression of neural cell adhesion molecule L1 in malignant gliomas and biological significance of L1 in glioma invasion. Cancer Res 56:1440-1444.

Jara PI, Boric MP, Saez JC (1995) Leukocytes express connexin 43 after activation with lipopolysaccharide and appear to form gap junctions with endothelial cells after ischemia-reperfusion. Proc Natl Acad Sci USA 92:7011-7015

Jongen W, Fitzgerald D, Asamoto M, Piccoli C, Slaga T, Gros D, Takeichi M, Yamasaki H (1991) Regulation of connexin 43-mediated gap junctional intercellular communication by $\mathrm{Ca} 2+$ in mouse epidermal cells is controlled by E-cadherin. J Cell Biol 114:545-555.

Jordan K, Chodock R, Hand AR, Laird DW (2001) The origin of annular junctions: a mechanism of gap junction internalization. J Cell Sci 114:763-773.

Kallio M, Sankila R, Jaaskelainen J, Karjalainen S, Hakulinen T (1991) A population-based study on the incidence and survival rates of 3857 glioma patients diagnosed from 1953 to 1984. Cancer 68:1394-1400.

Kang J, Jiang L, Goldman SA, Nedergaard M (1998) Astrocytemediated potentiation of inhibitory synaptic transmission. Nat Neurosci 1:683-692.

Keane R, Mehta P, Honig L, Loewenstein W, Rutishauser U (1988) Neural differentiation, NCAM-mediated adhesion, and gap junctional communication in neuroectoderm. J Cell Biol 106:1307-1319.

Kumar N, Gilula N (1996) The gap junction communication channel. Cell 84:381-388
Laing JG, Manley-Markowski RN, Koval M, Civitelli R, Steinberg TH (2001) Connexin45 interacts with zonula occludens-1 and connexin43 in osteoblastic cells. J Biol Chem 276:23051-23055.

Laird DW, Revel JP (1990) Biochemical and immunochemical analysis of the arrangement of connexin 43 in rat heart gap junction membranes. J Cell Sci 97:109-117.

Larsen WJ, Tung HN, Murray SA, Swenson CA (1979) Evidence for the participation of actin microfilaments and bristle coats in the internalization of gap junction membrane. J Cell Biol 83:576-587.

Leventhal C, Rafii S, Rafii D, Shahar A, Goldman SA (1999) Endothelial trophic support of neuronal production and recruitment from the adult mammalian subependyma. Mol Cell Neurosci 13:450-464.

Lin JH-C, Weigel H, Cotrina M, Liu S, Bueno E, Hansen A, Hansen T, Nedergaard M (1998) Gap junction mediated propagation and amplification of cell injury. Nat Neurosci 1:494-500.

Manjunath C, Goings G, Page E (1984) Detergent sensitivity and splitting of isolated liver gap junctions. J Membr Biol 78:147-155.

Marconi P, Tamura M, Moriuchi S, Krisky DM, Niranjan A, Goins WF, Cohen JB, Glorioso JC (2000) Connexin 43-enhanced suicide gene therapy using herpesviral vectors. Mol Ther 1:71-81.

Martini R, Carenini S (1998) Formation and maintenance of the myelin sheath in the peripheral nerve: roles of cell adhesion molecules and the gap junction protein connexin 32. Microsc Res Tech 41:403-415.

Matsuzaki F, Mege R-M, Jaffe S, Friedlander D, Gallin W, Goldberg J, Cunningham B, Edelman G (1990) cDNAs of cell adhesion molecules of different specificity induce changes in cell shape and border formation in cultured S180 cells. J Cell Biol 110:1239-1252.

Mazet F, Wittenberg BA, Spray DC (1985) Fate of intercellular junctions in isolated adult rat cardiac cells. Circ Res 56:195-204.

Mesnil M, Piccoli C, Tiraby G, Willecke K, Yamasaki H (1996) Bystander killing of cancer cells by herpes simplex virus thymidine kinase gene is mediated by connexins. Proc Natl Acad Sci USA 93:1831-1835.

Meyer R, Laird D, Revel J-P, Johnson R (1992) Inhibition of gap junction and adherens junction assembly by connexin and A-CAM antibodies. J Cell Biol 119:179-189.

Minkoff R, Parker S, Hertzberg E (1991) Analysis of distribution patterns of gap junctions during development of embryonic chick facial primordia and brain. Development 111:509-522.

Morris DC, Zhang Z, Davies K, Fenstermacher J, Chopp M (1999) High resolution quantitation of microvascular plasma perfusion in non-ischemic and ischemic rat brain by laser-scanning confocal microscopy. Brain Res Brain Res Protoc 4:185-191.

Morris DC, Davies K, Zhang Z, Chopp M (2000) Measurement of cerebral microvessel diameters after embolic stroke in rat using quantitative laser scanning confocal microscopy. Brain Res 876:31-36.

Nagy JI, Rash JE (2000) Connexins and gap junctions of astrocytes and oligodendrocytes in the CNS. Brain Res Brain Res Rev 32:29-44.

Namba H, Tagawa M, Miyagawa T, Iwadate Y, Sakiyama S (2000) Treatment of rat experimental brain tumors by herpes simplex virus thymidine kinase gene-transduced allogeneic tumor cells and ganciclovir. Cancer Gene Ther 7:947-953.

Nedergaard M (1994) Direct signaling from astrocytes to neurons in cultures of mammalian brain cells. Science 263:1768-1771.

Nose A, Nagafuchi A, Takeichi M (1988) Expressed recombinant cadherins mediate cell sorting in model systems. Cell 54:993-1001.

Omori Y, Yamasaki H (1998) Mutated connexin43 proteins inhibit rat glioma cell growth suppression mediated by wild-type connexin 43 in a dominant-negative manner. Int J Cancer 78:446-453.

Palmer TD, Willhoite AR, Gage FH (2000) Vascular niche for adult hippocampal neurogenesis. J Comp Neurol 425:479-494.

Peinado A, Yuste R, Katz L (1993) Extensive dye coupling between rat neocortical neurons during the period of circuit formation. Neuron 10:103-114.

Schiffer D (1997) Brain tumors. Biology, pathology, and clinical references. New York: Springer.

Schnadelbach O, Blaschuk OW, Symonds M, Gour BJ, Doherty P, Fawcett JW (2000) N-cadherin influences migration of oligodendrocytes on astrocyte monolayers. Mol Cell Neurosci 15:288-302.

Severs NJ, Slade AM, Powell T, Twist VW, Green CR (1990) Integrity of the dissociated adult cardiac myocyte: gap junction tearing and the mechanism of plasma membrane resealing. J Muscle Res Cell Motil 11:154-166.

Shinoura N, Chen L, Wani MA, Kim YG, Larson JJ, Warnick RE, Simon M, Menon AG, Bi WL, Stambrook PJ (1996) Protein and messenger RNA expression of connexin43 in astrocytomas: implications in brain tumor gene therapy. J Neurosurg 84:839-845.

Soroceanu L, Manning TJ, Sontheimer H (2001) Reduced expression of connexin-43 and functional gap junction coupling in human gliomas. Glia 33:107-117.

Takeichi M (1977) Functional correlation between cell adhesive properties and some cell surface proteins. J Cell Biol 75:464-474.

Takeichi M, Atsumi T, Yoshida C, Uno K, Okada T (1981) Selective adhesion of embryonal carcinoma cells and differentiated cells by $\mathrm{Ca} 2+$-dependent sites. Dev Biol 87:340-350. 
Toyofuku T, Yabuki M, Otsu K, Kuzuya T, Hori M, Tada M (1998) Direct association of the gap junction protein connexin-43 with ZO-1 in cardiac myocytes. J Biol Chem 273:12725-12731.

Toyofuku T, Akamatsu Y, Z hang H, Kuzuya T, Tada M, Hori M (2001) $\mathrm{c}$-Src regulates the interaction between connexin-43 and ZO-1 in cardiac myocytes. J Biol Chem 276:1780-1788.

Yuste R, Nelson DA, Rubin WW, Katz LC (1995) Neuronal domains in developing neocortex: mechanisms of coactivation. Neuron 14:7-17.

Zhang W, Couldwell WT, Simard MF, Song H, Lin JH, Nedergaard M (1999) Direct gap junction communication between malignant glioma cells and astrocytes. Cancer Res 59:1994-2003.

Zhang Z, Davies K, Prostak J, Fenstermacher J, Chopp M (1999) Quan- titation of microvascular plasma perfusion and neuronal microtubuleassociated protein in ischemic mouse brain by laser-scanning confocal microscopy. J Cereb Blood Flow Metab 19:68-78.

Zhang ZG, Tsang W, Zhang L, Powers C, Chopp M (2001) Upregulation of neuropilin-1 in neovasculature after focal cerebral ischemia in the adult rat. J Cereb Blood Flow Metab 21:541-549.

Zhu D, Caveney S, Kidder G, Naus C (1991) Transfection of C6 glioma cells with connexin 43 cDNA: analysis of expression, intercellular coupling, and cell proliferation. Proc Natl Acad Sci USA 88:1883-1887.

Zhu D, Kidder GM, Caveney S, Naus CC (1992) Growth retardation in glioma cells cocultured with cells overexpressing a gap junction protein. Proc Natl Acad Sci USA 89:10218-10221. 